\title{
PENYULUHAN PENDIDIKAN DAN PENGASUHAN POSITIF DIMASA PANDEMI COVID-19
}

\author{
ENENG GARNIKA ${ }^{1}$, BQ.ROHIYATUN ${ }^{2}$, LU'LUIN NAJWA ${ }^{3}$ \\ ${ }^{1}$ Bimbingan dan Konseling, ${ }^{2.3}$ Administrasi Pendidikan, UNDIKMA \\ Email korespondensi: lu'luinnajwa@ikipmataram.ac.id
}

\begin{abstract}
ABSTRAK
Tujuan dari pengabdian ini adalah meningkatkan pengetahuan pada guru dan orang tua tentang pendidikan dan pengasuhan positif dimasa Pandemi Covid-19. Meningkatkan pemahaman pada guru dan orang tua dampak positif dari Pendidikan dan pengasuhan positif di masa Pandemi Covid 19.Sasaran kegiatan adalah guru-guru dan orang tua peserta didik TK Dahlia Darmaji Kecamatan Kopang Kabupaten Lombok Tengah. Tahapan kegiatan pengabdian dimulai dari tahap persiapan, tahap pelaksanaan dan tahap evaluasi. Hasil kegiatan pengabdian ini adalah Pendidikan dan pengasuhan positif dapat mengembangkan aspek perkembangan anak dan dapat membuat anak bahagia sehingga dapat belajar lebih baik. Pendidikan dan pengasuhan positif dapat dilakukan dengan memberikan umpan balik positif, kata-kata yang menguatkan, guru dan orang tua memberikan motivasi, guru dan orang tua dapat melihat potensi baik anak, membangun hubungan sosial positif yang baik, serta memberi teladan dan mampu mengembangkan potensi terbaiknya.
\end{abstract}

Kata kunci: Pendidikan, pengasuhan positif, pandemi covid 19

\section{PENDAHULUAN}

Semenjak ditetapkannya Covid-19 sebagai pandemi pada bulan maret 2020. Untuk dunia pendidikan di Indonesia kondisi ini merupakan hal yang tak terduga bagi guru, orang tua, dan anak. Kebijakan belajar dari rumah, secara positif memberikan banyak waktu antara anak dan orang tua, secara tidak langsung mengembalikan fungsi keluarga sebagai tempat utama terjadinya pendidikan bagi anak. Mendampingi anak belajar secara daring, sebagian orang tua cenderung mengalami stress karena kesulitan dalam mengarahkan anak untuk belajar (Sabiq, 2020). Khususnya dalam pendidikan anak usia dini, masih banyak keluhan dari guru mengenai kesulitan dalam mengoperasikan computer, mengakses jaringan internet, internet tidak stabil, kesulitan mengkomunikasikan pesan dengan orang tua, kesulitan melakukan penilaian. Keluhan tidak hanya datang dari guru, orangtua juga mengeluhkan kesulitan mereka mendampingi anak belajar, tidak terbiasa menggunakan teknologi digital, tidak memahami maksud pesan dari guru, dll.

Anak pra sekolah berada pada masa lima tahun pertama yang disebut The Golden Years atau masa emas perkembangan anak. Anak pada usia tersebut memiliki potensi yang sangat besar untuk mengoptimalkan segala aspek perkembangannya. Pengasuhan merupakan proses interaksi antara orang tua dan anak dalam mendukung perkembangan fisik, emosi, intelektual, dan spiritual (Wong dalam Direktorat PAUD, 2020). Pengasuhan positif adalah pengasuhan yang dilakukan berdasarkan kasih saying, saling menghargai, pemenuhan dan perlindungan hak anak, hubungan yang hangat, bersahabat dan ramah antara anak dan orang tua, serta menstimulasi tumbuh kembang anak agar optimal.

Lokasi pengabdian ini adalah TK Dahlia Desa Darmaji Kecamatan Kopang Kabupaten Lombok Tengah. TK Dahlia merupakan TK yang proses penyelenggaraan pendidikannya masih dilakukan secara konvesional, berpusat pada guru, dan sarananya sangat terbatas. Orang tua melakukan pengasuhan dengan gaya otoriter anak-anak sekolah dituntut untuk mampu membaca menulis dan berhitung. Adapun yang menjadi tujuan dari pengabdian ini adalah: Meningkatkan pengetahuan pada Guru dan Orang tua tentang Pendidikan dan Pengasuhan Positif pada Anak Usia Dini dan Meningkatkan pemahaman pada guru dan orang tua dampak positif dari Pendidikan dan Pengasuhan Positif pada Anak Usia Dini. 


\section{METODE PELAKSANAAN KEGIATAN}

Penentuan suatu metode dalam melaksanakan suatu kegiatan dapat membantu suksesnya rangkaian kegiatan yang dimaksud. Dampak positif dari penerapan metode dalam suatu kegiatan yaitu dapat terlaksananya rangkaian kegiatan yang telah dirancang secara maksimal. Dalam pelaksanaan program penyuluhan menentukan metode yang akan diterapkan menjadi landasan utama. Metode yang digunakan dalam pelaksanaan penyuluhan Pendidikan dan Pengasuhan Positif di masa Pandemi Covid 19 antara lain: 1) Ceramah, Penyampaian materi secara langsung kepada peserta penyuluhan oleh nara sumber, dengan tujuan para guru-guru mengetahui dan memahami serta mampu mengimplementasikannya tentang materi penyuluhan yang disampaikan; 2) Demonstrasi, Nara sumber memberikan contoh-contoh Pendidikan dan Pengasuhan Positif di masa Pandemi Covid 19 dan selanjutnya mampu dipraktikkan oleh peserta sehingga pada akhirnya dapat diimplemetasikan oleh guru dan orang tua murid; 3) Tanya jawab, Memberikan kesempatan kepada peserta penyuluhan untuk bertanya serta menyampaikan pendapat seputar materi penyuluhan yang sudah disampaikan.

Adapun tahapan yang dilakukan yaitu Tahapan Persiapan, pada tahap ini dilakukan beberapa kegiatan yaitu: (a) Survei lokasi kegiatan penyuluhan, (b) Melakukan koordinasi dengan pihak sekolah untuk menentukan kesiapan para guru yang akan menjadi peserta dalam penyuluhan (c) menyiapkan alat dan bahan yang digunakan dalam proses pelatihan, (d) menyiapkan tempat dan waktu penyuluhan, (e) Koordinasi dengan anggota tim untuk membicarakan siapa yang akan menjadi pemateri dalam kegiatan penyuluhan tersebut.

Untuk tahapan pelaksanaan, kegiatan yang dilakukan yaitu: (a) melakukan ceramah untuk memberikan pemahaman mengenai pengasuhan positif. (b) melakukan peragaan/demonstrasi dengan memberikan contoh-contoh cara penerapan pengasuhan efektif kepada orang tua dan guru. (c) memberikan pendampingan; membimbing para guru dan orang tua merancang kegiatan yang dapat mendorong pengasuhan positif. Kemudian Tahap Evaluasi, pada tahap ini kegiatan yang dilakukan adalah memberikan tes di awal dan setelah kegiatan penyuluhan. Tes awal bertujuan untuk mengetahui pemahaman dan kemampuan awal guru dan orang tua tentang pengasuhan positif, sedangkan lembar pengamatan digunakan untuk mengetahui kegiatan guru dan orang tua saat penyuluhan.

\section{HASIL DAN PEMBAHASAN}

Kegiatan pengabdian ini di awali dengan observasi dan kunjungan ke TK Dahlia Desa Darmaji Kecamatan Kopang Kabupaten Lombok Tengah. Kegiatan observasi dilakukan untuk mendapatkan informasi terkait dengan pemahaman orang tua dan guru tentang pengasuhan positif anak usia dini. Berdasarkan hasil pengabdian ada beberapa hal yang harus dibahas yaitu: pertama berkaitan dengan antusias guru dan orang tua untuk mengikuti kegiatan, hal ini dikarenakan guru dan orang tua sangat membutuhkan informasi mengenai pengasuhan positif terlebih lagi di saat masa pandemi. Motivasi yang tinggi dari guru dan orang tua memberikan kontribusi yang besar bagi lancarnya kegiatan pengabdian.

Dari hasil kegiatan pengabdian menunjukkan bahwa pemahaman guru dan orang tua terkait materi yang disampaikan dikategorikan baik. Dengan adanya penyuluhan pengasuhan positif ini guru dan orang tua memahami prinsip-prinsip pengasuhan positif antara lain (Kemendikbud, 2020:5-6): (a) memahami setiap anak unik dan memiliki impian; (b) selalu mencari cara atau strategi baru untuk menyikapi perubahan; (c) menerima anak apa adanya; (d) mendukung dan memfasilitasi anak untuk tumbuh dan berkembang; (e) bermain dan bergembira bersama. Beberapa hal yang perlu dipahami orang tua dalam penerapan pengasuhan positif yaitu: (1) memahami tahap perkembangan anak,; (2) memahami komunikasi efektif; dan (3) memahami disiplin positif. 

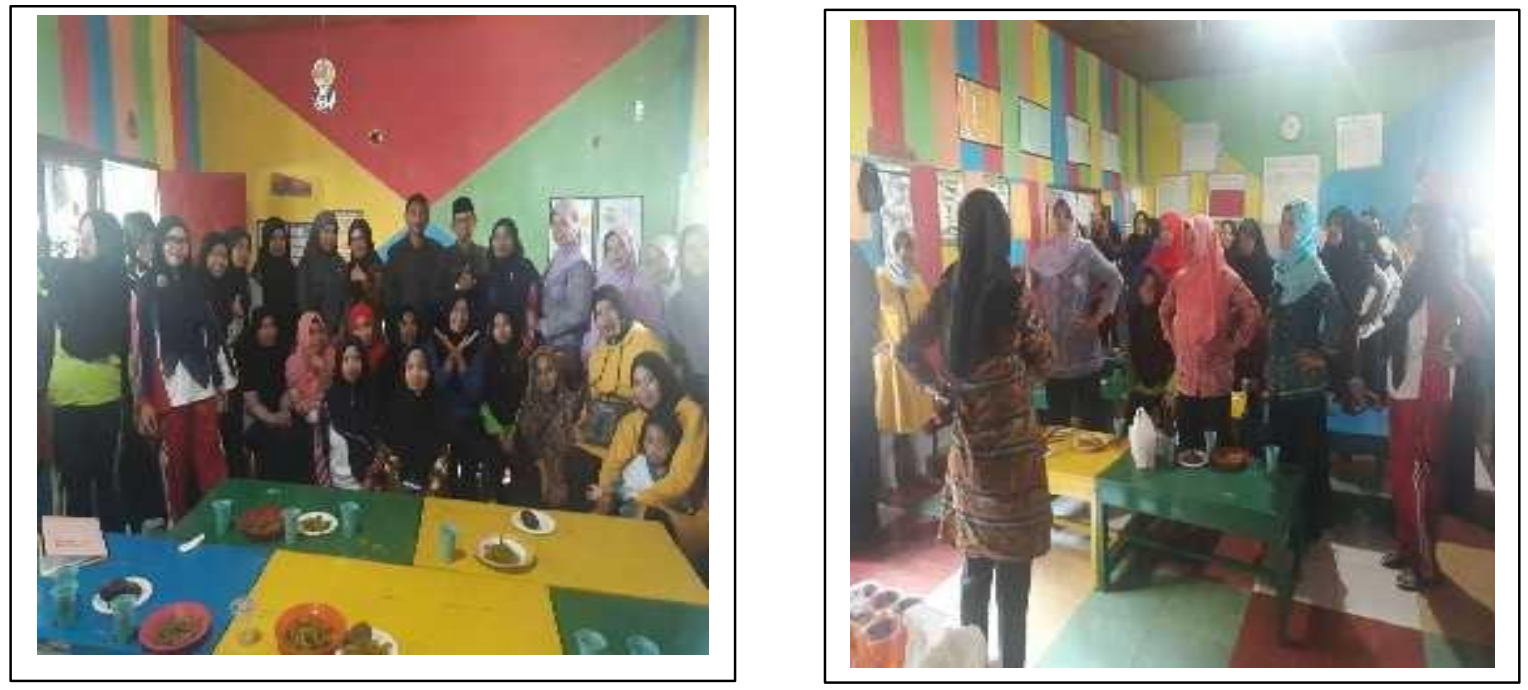

\section{Gambar 1. Foto Pelaksanaan Kegiatan}

Salah satu program pengasuhan positif diantaranya adalah Positive Parenting Program atau Triple P: Program Pengasuhan Positif. Tujuan utama dari triple $\mathrm{P}$ adalah pengembangan kapasitas individu untuk pengaturan diri (Sanders, 2008). Pengaturan diri adalah proses dimana individu diajarkan keterampilan untuk mengubah perilaku mereka sendiri dan menjadi solusi dalam masalah di lingkungan sosial yang lebih luas yang berhubungan dengan pengasuhan dan keluarga (Karoly, dalam Sanders, 2008). Menurut Gloria, (2020) menyatakan bahwa dengan adanya pandemi COVID-19 ini memiliki hikmah tersendiri untuk orang tua, karena orang tua bisa memonitoring anak nya secara langsung juga dapat melakukan bimbingan secaara langsung dalam proses pembelajaran anak-anaknya, sehingga anak akan lebih dekat dengan orang tuanya serta orang tua akan mengetahui kesulitan yang dihadapi anaknya dan peran orang tua adalah untuk membantu kesulitan-kesulitan tersebut.

\section{KESIMPULAN}

Kegiatan Pengabdian ini sangat bermanfaat dalam meningkatkan kinerja guru TK dalam kegiatan belajar dan mengajar dan meningkatkan kualitas pengasuhan para orang tua. Metode pembelajaran pada Anak Usia Dini dengan Tingkat sekolah memiliki perbedaan yang sangat signifkan. Pada metode pembelajaran TK, guru dituntut lebih kreatif dan inovatif dalam implementasi prosesnya sehingga seluruh aspek perkembangan anak dapat terstimulasi dengan baik dan anak-anak dapat bertumbuh serta berkembang secara baik pula.

\section{DAFTAR PUSTAKA}

Direktorat PAUD KEMDIKBUD. 2020. Pengasuhan Positif. Kemdikbud: Jakarta.

Gloria. (2020). Sehat Mental Selama di Rumah dengan Aktivitas Positif Bersama Keluarga. Ugm.Ac.Id.https://ugm.ac.id/id/newsPdf/19175-sehat-mental-selama-di-rumahdengan-aktivitas-positif-bersama-keluarga

Sabiq, A.F. (2020). Persepsi orang tua siswa tentang kegiatan belajar di rumah sebagai dampak penyebaran Covid-19. Civic-Culture: Jurnal Ilmu Pendidikan PKn dan Sosial Budaya, 4 (1), 01-07

Sanders, M. R. (2008). Triple P-Positive Parenting Program as a Public Health Approach to Strengthening Parenting. Journal of Family Psychology. https://doi.org/10.1037/08933200.22.3.506 